\title{
Ad-Deenar
}

Doi: $10.30868 /$ ad.v4i02.974

\section{FACTORS AFFECTING COMMUNITY INTEREST \\ IN SHARIA BANK SAVING PRODUCTS \\ (Studies on the Community of South Tangerang City)}

\section{FAKTOR-FAKTOR YANG MEMPENGARUHI MINAT MASYARAKAT \\ PADA PRODUK TABUNGAN BANK SYARIAH \\ (Studi Pada Masyarakat Kota Tangerang Selatan)}

\author{
Intan Lilis Sugiarti, Erika Amelia, Ade Ananto Terminanto \\ Program Studi Perbankan Syariah UIN Syariaf Hidayatullah Jakarta \\ intanlilissugiarti11@gmail.com \\ erika.amalia@uinjkt.ac.id \\ ade_terminanto@yahoo.com
}

\begin{abstract}
This research was conducted to find factors that influence people's preferences on Islamic bank savings products. This study uses primary data in the form of a questionnaire distributed to the people of South Tangerang. They have been or have been a sharia bank savings customer. This study obtained a sample of 133 respondents. To analyze this study, researchers used a factor analysis test and Chi-Square (X2) test using SPSS version 24. The factor analysis test results from this study indicate that nine factors can influence people's preferences on Islamic bank savings products. Factors formed successively include guarantee and equality of profit-sharing results, product feature factors, product quality factors, profit-sharing distribution factors, environmental factors, sharia understanding factors, sharia mechanism factors, usability factors, and shariah compliance factors. The chi-square test analysis showed that the characteristics of respondents in the form of gender, age, occupation, last education, and address have a relationship with nine factors formed.
\end{abstract}

Keywords: factor analysis, community preferences, sharia savings, chi-square

ABSTRAK

Penelitian ini dilakukan untuk menemukan faktor-faktor yang mempengaruhi preferensi masyarakat pada produk tabungan bank syariah. Penelitian ini menggunakan data primer berupa kuesioner yang dibagikan kepada masyarakat kota Tangerang Selatan yang menjadi dan/atau pernah menjadi nasabah tabungan bank syariah. Penelitian ini mendapatkan sampel sebanyak 133 responden. Untuk menganalisis penelitian ini peneliti menggunakan uji analisis faktor dan uji Chi-Square $\left(\mathrm{X}^{2}\right)$ dengan menggunakan SPSS versi 24. Hasil uji analisis faktor dari penelitian ini menunjukkan terdapat 9 faktor yang dapat mempengaruhi preferensi masyarakat pada produk tabungan bank syariah. Faktor - faktor yang terbentuk berturut turut antara lain: faktor jaminan dan kesederajatan bagi hasil, faktor fitur produk, faktor kualitas produk, faktor distribusi bagi hasil, faktor lingkungan, faktor pemahaman syariah, faktor mekanisme syariah, faktor kegunaan, dan faktor kesesuaian syariah. Dari analisis uji Chi-Square pada penelitian ini menunjukkan bahwa karakteristik responden yang berupa jenis kelamin, usia, pekerjaan, pendidikan terakhir dan alamat memiliki keterkaitan dengan 9 faktor yang terbentuk.

Kata kunci: analisis faktor, minat masyarakat, tabungan Syariah, chi-square 


\section{A. Pendahuluan}

Perkembangan ekonomi Indonesia pada era sekarang terus menunjukan pergerakan yang positif. Kemajuan perekonomian suatu negara dapat dilihat dari berbagai macam tolok ukur. Salah satu sektor yang menjadi tolok ukur penilaian ekonomi suatu negara adalah sektor perbankan. Semakin maju suatu negara, maka semakin besar peranan perbankan dalam mengendalikan negara tersebut. Secara umum, bank adalah lembaga intermediaries yang kegiatan operasionalnya yaitu menghimpun dana dari masyarakat dan menyalurkannya kembali kepada masyarakat dalam bentuk pinjaman. Bank menjadi salah satu lembaga yang berpengaruh bagi masyarakat dalam menjalankan lalu lintas ekonomi (Kashmir, 2012) .

Meskipun perkembangannya belum sebesar bank konvensional, pertumbuhan bank syariah dinilai terus meningkat. Untuk saat ini bank syariah di Indonesia sudah mampu mencapai pangsa pasar 5,9\% dengan total asset $\operatorname{Rp} 471,94$ triliun. Jumlah asset tersebut dipengaruhi oleh meningkatnya jumlah nasabah bank syariah seiring berjalannya waktu, terutama untuk nasabah produk tabungan (Mulya E Siregar, 2019).

Tabungan menjadi salah satu produk bank syariah yang paling dekat dengan nasabah. Dimana produk tabungan merupakan produk yang lebih mudah dan paling liquid yang digunakan oleh nasabah baik dari segi legalitas persyaratan sampai dengan fasilitas yang dapat digunakan. Keputusan masyarakat untuk menggunakan dan memilih akad tabungan yang akan digunakan dipengaruhi oleh beberapa hal. Pengaruh tersebut dapat berasal baik dari sisi nasabah itu sendiri maupun dari pihak bank. Sebagai sebuah lembaga keuangan, bank syariah diharapakan mampu menggunakan strategi yang tepat guna menghimpun dana dari masyarakat. Bank syariah harus mampu menerapkan strategi pemasaran yang tepat untuk menyampaikan informasi terhadap nasabah terkait produk mereka.

Proses pengambilan keputusan yang dilakukan oleh konsumen seringkali mengalami beberapa masalah yang didasari oleh faktor-faktor kompleks dan menyangkut beberapa hal penentu keputusan itu sendiri. Sehingga pihak bank diharapkan dapat lebih memahami apa saja faktor-faktor yang memepengaruhi dalam keputusan konsumen untuk melakukan pembelian/menggunakan produk bank. Dengan demikian pihak pemasaran bank dapat lebih mudah memahami dalam pemenuhan keinginan konsumen. Faktorfaktor yang mempengaruhi biasanya 
berupa pemasaran ekonomi, teknologi, politik, sosial, budaya serta karakterisitik nasabah (Aulia Viranti Firza dan Ginanjar. A., 2015).

Menurut Ferdinand (2014) minat beli dapat diidentifikasi melalui berbagai indikator. Pertama, minat transaksional yaitu kecenderungan konsumen untuk membeli produk atau jasa. Kedua, minat refrensial merupakan kecenderungan konsumen untuk mereferensikan atau menginformasikan produk atau jasa kepada orang lain. Ketiga, minat prefensial, yaitu minat yang menggambarkan perilaku konsumen yang memiliki minat utama pada produk dan jasa tersebut. Keempat, minat eksploratif merupakan minat yang menggambarkan perilaku konsumen yang selalu mencari informasi-informasi lain mengenai produk dan jasa yang diminatinya sehingga tahu sifat-sifat positif yang terdapat dalam produk atau jasa tersebut (A Ferdinand, 2014).

Pada kenyataannya persepsi dan sikap masyarakat terhadap bunga bank dan sistem bagi hasil sangat beragam. Masyarakat cenderung menerima bunga dan sebagian besar menerima sistem bagi hasil dengan tetap menerima bunga tapi ada juga yang menolak bunga. Beragamnya persepsi, sikap dan perilaku masyarakat terhadap Bank Syariah, di antaranya disebabkan oleh rendahnya pemahaman masyarakat terhadap Bank Syariah, terutama yang disebabkan dominasi bank konvensional (Rusdianto Hutomo \& Chanafi Ibrahim, 2016).

Di sisi lain, menurut Divisi Pengembangan Perbankan Syariah OJK Hanifah Awaliya (2019) mengungkapkan tantangan dalam industri perbankan syariah, seperti market share asset yang masih harus ditingkatkan. Selain itu untuk menjangkau nasabah bank syariah masih memiliki permasalahan terkait variasi produk, fitur layanan perbankan syariah yang belum sepadan dengan konvensional, penggunaan teknologi masih belum optimal dan keterbatasan akses terhadap produk syariah (www.ojk.go.id) (Otoritas Jasa Keuangan, 2019).

Sementara lain tingkat performance produk dapat diukur atau dilihat pada tingkat kepentingannya berdasarkan atribut-atribut kunci yang sudah diidentifikasi konsumen (Fandy Tjiptono, 2014). Keputusan mengenai atribut ini mempengaruhi reaksi konsumen terhadap suatu produk (Kotler, P dan Armstrong G., 2012).

Salah satu faktor lain yang mempengaruhi nasabah untuk menyimpan dananya di bank syariah karena faktor bagi hasil. Perusahaan yang dapat mengelola dengan baik dana yang 
disimpan nasabah maka bagi hasil yang diperoleh nasabah akan lebih baik pula (Raihanah Daulay, 2014). Keputusan sebagai pemilihan suatu tindakan dua atau lebih pemilihan alternatif. Seorang konsumen yang hendak melakukan pilihan maka ia harus memiliki pilihan alternatif. Banyaknya macam bank syariah dan produk tabungan mudharabah yang ditawarkan menjadikan banyak alternatif. Jika konsumen telah memutuskan alternatif yang akan dipilih dan mungkin penggantinya jika diperlukan, maka ia akan melakukan pembelian (Ujang Sumarwan, 2011).

Sesuai dengan permasalahan yang ada, tujuan yang ingin dicapai penulis adalah untuk mengumpulkan bukti empiris mengenai bagaimana pengaruh variabel persepsi syariah, atribut produk, dan bagi hasil terhadap minat masyarakat pada produk tabungan Bank Syariah dan adanya hubungan antara karakteristik responden dengan masing-masing faktor yang mempengaruhi minat masyarakat untuk menggunakan produk tabungan bank syariah.

\section{B. KAJIAN TEORITIK}

\section{Minat Beli}

Minat beli merupakan pernyataan mental konsumen yang merefleksikan rencana pembelian suatu produk dengan merek tertentu pengetahuan tentang niat beli konsumen terhadap produk perlu diketahui oleh para pemasar untuk mendeskripsikan perilaku konsumen pada masa yang akan datang. Minat beli terbentuk dari sikap konsumen terhadap suatu produk hal tersebut berasal dari keyakinan konsumen terhadap kualitas produk. Semakin rendah keyakinan konsumen terhadap suatu produk akan menyebabkan menurunkan minat beli konsumen. Minat (Interest) digambarkan sebagai situasi dimana konsumen belum melakukan suatu tindakan, yang dapat dijadikan dasar untuk memprediksi perilakuk atau tindakan tersebut. Minat merupakan perilaku yang muncul sebagai respon terhadap suatu objek yang menunjukkan keinginan pelanggan untuk melakukan pembelian (Phillip Kotler dan Armstrong G., 2012).

Menurut Ferdinand (2014), bahwa minat beli diidentifikasi melalui indikator-indikator sebagai berikut:

a. Minat transaksional, yaitu kecenderungan seseorang untuk membeli produk.

b. Minat referensial, yaitu kecenderungan seseorang untuk mereferensikan produk kepada orang lain.

c. Minat preferensial, yaitu minat yang menggambarkan perilaku seseorang 
yang memiliki preferensi utama pada produk tersebut. Preferensi ini hanya dapat digantikan jika terjadi sesuatu dengan produk preferensinya.

d. Minat eksploratif, minat ini menggambarkan perilaku seseorang yang selalu mencari informasi mengenai produk yang diminatinya dan mencari informasi untuk mendukung sifat-sifat positif dari produk tersebut.

\section{Definisi Persepsi}

Menurut Veithzal (2017), Persepsi diartikan sebagai tanggapan (peristiwa) langsung dari sesuatu, proses seseorang mengetahui beberapa hal melalui penginderaannya. Dengan demikian yang dimaksud dengan persepsi adalah proses dari seseorang dalam memahami lingkunganya yang melibatkan pengorganisasian dan penafsiran sebagai rangsangan dalam suatu pengalaman psikologi. Persepsi juga diartikan sebagai suatu proses dimana individu-individu mengorganisasikan dan menafsirkan kesan indra mereka agar memberi makna kepada lingkungan mereka. Disamping itu, persepsi dapat dilihat dari proses kognitif yang dialami oleh setiap orang dalam memahami informasi tentang lingkungannya, baik lewat penglihatan, pendengaran, penghayatan, perasaan, dan penciuman.
Selanjutnya dikatakan bahwa kunci untuk memahami persepsi adalah terletak pada pengenalan bahwa persepsi merupakan penafsiran yang unik terhadap situasi dan bukanya suatu pencatatan yang benar terhadap situasi.

Adapun beberapa faktor yang mempengaruhi pengembangan persepsi seseorang yaitu:

a. Psikologi, Persepsi seseorang mengenai segala sesuatu yang terjadi di alam dunia ini sangat dipengaruhi oleh keadaan psikologi

b. Famili, Pengaruh yang besar terhadap anak-anak adalah familinya, orang tua yang telah mengembangkan suatu cara yang khusus di dalam memahami dan melihat kenyataan di dunia ini, banyak sikap dan persepsi-persepsi mereka yang diturunkan kepada anak-anaknya.

c. Kebudayaan dan lingkungan masyarakat tertentu juga merupakan salah satu faktor yang kuat dalam mempengaruhi sikap, nilai dan cara seseorang memandang dan memahami keadaan

Menurut Walgito (2010), bahwa faktor yang mempengaruhi pengembangan persepsi seseorang yaitu:

a. Faktor Internal, berupa persepsi berkaitan dengan kebutuhan 


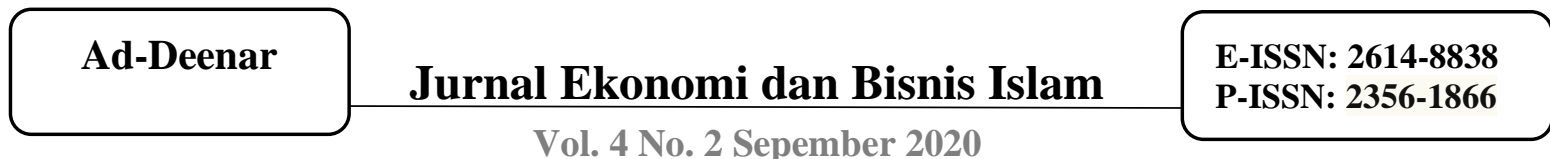

Vol. 4 No. 2 Sepember 2020

psikologis, latar belakang pendidikan, alat indera, syaraf atau pusat susunan syaraf, kepribadian dan pengalaman penerimaan diri serta keadaan individu pada waktu tertentu.

b. Faktor Eksternal, berupa obyek yang dipersepsikan atas orang dan keadaan, intensitas rangsangan, lingkungan, kekuatan rangsangan akan turut menentukan didasari atau tidaknya rangsangan tersebut.

\section{Atribut produk}

Atribut produk adalah suatu komponen yang merupakan sifat-sifat produk yang menjamin bahwa produk tersebut dapat memenuhi kebutuhan dan keinginan yang diharapakan oleh konsumen atau pembeli (Gitosudarmo, I., 2014). Setiap produk memiliki atribut atau sifat yang berbeda, dari atribut inilah suatu produk dapat dilihat oleh para konsumen. Konsumen memiliki variasi dalam menentukan atribut mana yang paling relevan menurut pertimbangan mereka dan mereka akan menaruh perhatian terbesar pada atribut yang berhubungan dengan kebutuhan mereka.

Unsur-unsur atribut produk meliputi ( Fandy Tjiptono, 2015): a. Harga, b. Merek, c. Kemasan, d. Pemberian Label, f. Jaminan (garansi), g. Layanan pelengkap. Kmudian Kotler dan Armstrong, (2012) mengungkapkan, bahwa unsur-unsur atribut produk: a. Kualitas Produk; b. Fitur Produk; dan c. Gaya dan Desain Produk.

\section{Bagi Hasil}

Menurut Antonio (2012), bagi hasil adalah suatu sistem pengolahan dana dalam perekonomian Islam yakni pembagian hasil usaha antara pemilik modal (shahibul maal) dan pengelola (Mudharib) (M.Syai'i Antonio, 2012). Pembayaran imbalan bank syariah kepada pemilik dana dalam bentuk bagi hasil besarnya sangat tergantung dari pendapatan yang diperoleh sebagai mudharib atas pengelolaan dana mudharabah tersebut (Wiroso dkk, 2010).

Dalam sistem bagi hasil terdapat prinsip-prinsip untuk menjalankan aktivitasnya yaitu:

a. Prinsip Keadilan dan Kehatihatian, tercermin dari penerapan imbalan atas dasar bagi hasil dan pengambilan margin keuntungan yang disepakati bersama.

b. Prinsip Kesederajatan, dimana menempatkan nasabah penyimpan dana, nasabah pengguna dana, maupun bank 


\section{Ad-Deenar}

pada kedudukan yang sama dan sederajat.

c. Prinsip Ketentraman. Produkproduk Bank Syariah telah sesuai dengan prinsip dan kaidah muamalah Islam.

d. Distribusi pembagian hasil usaha bank syariah dengan nasabah penghimpunan dana hanya didasarkan pada akad mudharabah.

\section{Simpanan Tabungan}

Pengertian tabungan menurut undang undang perbankan Nomor 10 tahun 1998 adalah simpanan yang penarikannya hanya dapat dilakukan menurut syarat- syarat tertentu yang disepakati, tetapi tidak dapat ditarik dengan cek, bilyet giro dan/atau alat lainnya yang dipersamakan dengan itu. Sarana bank dalam simpanan tabungan ada bermacam macam seperti: buku tabungan, slip penarikan, kuitansi, kartu yang terbuat dari plastic.

\section{Kerangka Pemikiran}

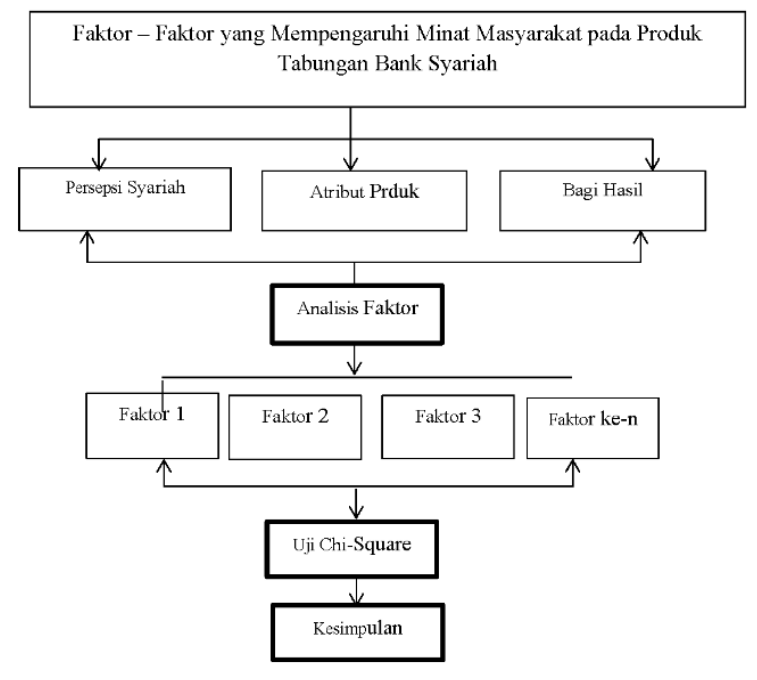

\section{METODE PENELITIAN}

Penelitian ini merupakan penelitian dengan analisis multivariat. Analisis multivariat ini merujuk kepada teknik statistika tertentu yang menganalisis banyak variabel secara simultan. Metode yang digunakan dalam peneltiaian ini adalah metode analisis faktor dengan 
Principle Component Analisys dan uji Chi-Square. Penelitian ini juga menggunakan pendekatan hipotesis hubungan (asosiatif) untuk menunjukkan dugaan tentang hubungan antara dua variabel atau lebih. Jenis data yang digunakan adalah data primer yang diperoleh dengan menggunakan metode survey melalui kuesioner dan analisis data kuantitatif. Kuesioner didistribusikan kepada responden yang berdomisili di daerah Tangerang Selatan. Variabel-variabel dalam penelitian ini yaitu persepsi syariah, atribut produk, dan bagi hasil. Studi kasus pada penelitian ini adalah masyarakat yang berdomisili di kota Tangerang Selatan dan sekitarnya khususnya yang sedang atau pernah menjadi nasabah bank syariah.

Teknik pengambilan sampel yang digunakan oleh penulis adalah metode non probability sampling, yaitu teknik pengambilan sampel yang tidak memberikan peluang yang sama bagi setiap unsur (anggota) populasi untuk dipilih menjadi anggota sampel. Pengambilan sampel yang digunakan pada penelitian ini merujuk pada teori Santoso (2017) yang menyebutkan bahwa dalam analisis faktor jumlah sample yang dianjurkan secara umum adalah 50 sampai 100 sampel dari kuesioner yang disebar diperoleh 133 responden yang sesuai dengan kriteria dalam penelitian ini (Singgih Santoso, 2017).

\section{PEMBAHASAN}

\section{Hasil Analisis Faktor}

Dari data responden yang terlah diolah, hasil output pada KMO and Barlett's Test yang terdapat pada tabel di atas besarnya adalah 0,776, dengan tingkat signifikansi 0,000. Oleh karena angka KMO and Barlett's Test lebih besar dari 0,5, dan tingkat signifikansi lebih kecil dari 0,05, maka variabel dan sampel yang ada sudah dapat dianalisis lebih lanjut.

Dalam penentuan variabel (indikator 130) ini diperoleh bahwa keseluruhan variabel yang ada telah memenuhi persyaratan, yaitu nilai MSA $>0,50$, sehingga variabel masih bisa diprediksi dan dianalisis lebih lanjut dalam analisis faktor.

Dalam penelitian ini penentuan jumlah faktor didasarkan pada nilai eigenvalue dengan kriteria bahwa angka eigenvalue $<1$ tidak digunakan dalam menghitung jumlah faktor yang terbentuk. Untuk menentukan jumlah faktor tersebut dapat dilihat pada tabel Total Variance Explained dari program SPSS 
Tabel. Total Variance Explained

\begin{tabular}{|c|c|c|c|c|c|c|c|c|c|}
\hline \multirow[b]{2}{*}{$\begin{array}{l}\text { Compo } \\
\text { nent }\end{array}$} & \multicolumn{3}{|c|}{ Initial Eigenvalues } & \multicolumn{3}{|c|}{$\begin{array}{c}\text { Extraction Sums of Squared } \\
\text { Loadings }\end{array}$} & \multicolumn{3}{|c|}{$\begin{array}{c}\text { Rotation Sums of Squared } \\
\text { Loadings }\end{array}$} \\
\hline & Total & $\begin{array}{c}\% \text { of } \\
\text { Variance }\end{array}$ & $\begin{array}{c}\text { Cumulative } \\
\%\end{array}$ & Total & $\begin{array}{c}\% \text { of } \\
\text { Variance }\end{array}$ & $\begin{array}{c}\text { Cumulative } \\
\%\end{array}$ & Total & $\begin{array}{c}\% \text { of } \\
\text { Variance }\end{array}$ & $\begin{array}{c}\text { Cumulative } \\
\%\end{array}$ \\
\hline 1 & 7,138 & 23,793 & 23,793 & 7,138 & 23,793 & 23,793 & 2,876 & 9,585 & 9,585 \\
\hline 2 & 2,748 & 9,161 & 32,955 & 2,748 & 9,161 & 32,955 & 2,847 & 9,489 & 19,074 \\
\hline 3 & 2,048 & 6,825 & 39,780 & 2,048 & 6,825 & 39,780 & 2,810 & 9,366 & 28,440 \\
\hline 4 & 1,750 & 5,832 & 45,612 & 1,750 & 5,832 & 45,612 & 2,531 & 8,435 & 36,876 \\
\hline 5 & 1,590 & 5,299 & 50,911 & 1,590 & 5,299 & 50,911 & 2,424 & 8,080 & 44,956 \\
\hline 6 & 1,429 & 4,763 & 55,675 & 1,429 & 4,763 & 55,675 & 2,300 & 7,666 & 52,622 \\
\hline 7 & 1,313 & 4,378 & 60,053 & 1,313 & 4,378 & 60,053 & 1,682 & 5,606 & 58,228 \\
\hline 8 & 1,192 & 3,974 & 64,027 & 1,192 & 3,974 & 64,027 & 1,505 & 5,017 & 63,245 \\
\hline 9 & 1,069 & 3,562 & 67,589 & 1,069 & 3,562 & 67,589 & 1,303 & 4,344 & 67,589 \\
\hline 10 & ,964 & 3,214 & 70,802 & & & & & & \\
\hline 11 & ,829 & 2,764 & 73,566 & & & & & & \\
\hline 12 &, 765 & 2,551 & 76,117 & & & & & & \\
\hline 13 & ,718 & 2,393 & 78,510 & & & & & & \\
\hline 14 & ,653 & 2,178 & 80,688 & & & & & & \\
\hline 15 & ,631 & 2,104 & 82,792 & & & & & & \\
\hline 16 &, 570 & 1,899 & 84,691 & & & & & & \\
\hline 17 &, 537 & 1,789 & 86,480 & & & & & & \\
\hline 18 &, 505 & 1,683 & 88,163 & & & & & & \\
\hline 19 & ,477 & 1,591 & 89,754 & & & & & & \\
\hline 20 & ,421 & 1,402 & 91,155 & & & & & & \\
\hline 21 & ,392 & 1,305 & 92,461 & & & & & & \\
\hline 22 & ,355 & 1,183 & 93,644 & & & & & & \\
\hline 23 & ,343 & 1,142 & 94,785 & & & & & & \\
\hline 24 & ,298 & ,993 & 95,779 & & & & & & \\
\hline 25 & ,266 & ,888 & 96,667 & & & & & & \\
\hline 26 & ,246 & ,819 & 97,486 & & & & & & \\
\hline 27 & ,231 & ,769 & 98,255 & & & & & & \\
\hline 28 & ,203 & 677 & 98,932 & & & & & & \\
\hline 29 &, 174 &, 579 & 99,511 & & & & & & \\
\hline 30 &, 147 & ,489 & 100,000 & & & & & & \\
\hline
\end{tabular}

Extraction Method: Principal Component Analysis.

Pada tabel Total Variance Explained, terlihat bahwa terdapat 9 (sembilan) faktor yang terbentuk dari 30 faktor yang ada.
Hal ini diketahui dengan pembentukan jumlah faktor dalam analisis faktor jika eigenvalue $<1$, maka tidak dapat 


\section{Ad-Deenar}

digunakan dalam pembentukan faktor.

Setelah terbentuk faktor, maka tahap selanjutnya adalah menginterpretasikan faktor

terbentuk.

Tabel. Rotated Component Matrix ${ }^{a}$

\begin{tabular}{|c|c|c|c|c|c|c|c|c|c|}
\hline & \multicolumn{9}{|c|}{ Component } \\
\hline & 1 & 2 & 3 & 4 & 5 & 6 & 7 & 8 & 9 \\
\hline PS1 &,- 051 & ,153 & ,031 & ,224 &,- 054 & ,130 &,- 003 & ,719 & ,101 \\
\hline PS2 & ,002 & , 148 & ,076 & ,099 & ,047 & 699 & , 137 & ,279 & ,021 \\
\hline PS3 & ,018 & , 152 & ,035 & ,077 & ,010 & ,828 &,- 033 & 101, & -005 \\
\hline PS4 &,- 112 & ,018 & ,057 & ,067 & , 104 & ,644 & ,045 &,- 391 & ,377 \\
\hline PS5 &, 032 & ,059 & ,085 & ,025 & ,208 & ,005 & ,790 &,- 097 & ,209 \\
\hline PS6 & 193, & 188 & 136, & -,106 & 489, & 191, &,- 175 & ,525 & 039 \\
\hline PS7 & 099, &,- 033 & ,130 & ,070 & ,548 & ,333 & 187, & ,345 & 198 \\
\hline PS8 &,- 037 & 103 & 117, & 146 & ,840 &,- 025 & ,064 &,- 041 & ,025 \\
\hline PS9 &,- 151 & 216 & ,054 & ,062 & ,833 & 016, & 103 &,- 072 & ,004 \\
\hline PS10 & ,002 & 202 & 268, & ,302 & 113 & 251 & 208 & , 156 & ,610 \\
\hline PS11 & 147, &, 600 & 255, & ,139 & ,334, & ,060 &,- 124 & ,010, &,- 107 \\
\hline AP1 & ,014, & ,172 & ,809, & ,088, &,- 072 & ,027, & ,081 & ,043, & ,002 \\
\hline AP2 & 204 & 119, & ,742 &,- 016 & 223 & ,021 &,- 073 & ,066 & ,045 \\
\hline AP3 & 112, & ,031 & ,808 &,- 035 & 138, & ,038, & ,095 & ,007, & 163 \\
\hline AP4 &,- 185 & 204 & ,594 & 371 & ,089 & ,099 & ,048 &,- 056 &,- 029 \\
\hline AP5 & 323, & ,541 & ,055 & 059, & ,056 & 021 & 158, & 127, & ,500 \\
\hline AP6 & ,209 & ,674 & , 144 &,- 042 & ,004 & , 162 & ,318 & ,091 &,- 012 \\
\hline AP7 & ,080 & ,690 & ,081 & ,144 & ,085 & ,097 &,- 079 & 092 & ,305 \\
\hline AP8 & 127, & ,358 & 197, & 286, & 284 & 265 & 159 &,- 136 & 053 \\
\hline AP9 & ,034 & ,565 &,- 030 & 159, &,- 005 & 145, & ,546 & ,094 &,- 134 \\
\hline AP10 &,- 104 & ,529 & 221 & ,237 & 228 & ,112 & ,044 & ,070 & ,047 \\
\hline BS1 &,- 032 & , 178 & ,013 &, 591 & , 128 & ,402 &,- 086 &, 078 &,- 092 \\
\hline BS2 & ,178 & ,076 & ,073 & ,635 &, 044 & , 103 &,- 084 & ,209 & ,336 \\
\hline BS3 & 294 & ,046 & ,010 & ,658 & 149, &,- 087 & 269 & 077, & ,097 \\
\hline BS4 & ,340 &, 352 & ,129 &, 562 &, 116 &,- 021 &,- 173 &,- 363 & ,108 \\
\hline BS5 &, 021 & 165 & ,216 &, 590 &,- 040 & 181, & 445, & ,099 &,- 110 \\
\hline BS6 & ,810 & 196, & 078, & ,011 & ,061 &,- 073 &,- 231 &,- 123 & 029 \\
\hline BS7 & 414, & ,054 & ,430 & 256 & ,035 & ,315 &,- 022 & ,053 &,- 359 \\
\hline BS8 & ,808 & ,007, & 114, & 218 &,- 038 &,- 053 & ,189 & 151 & ,046 \\
\hline BS9 & ,883 & 105, & 015, & 095, &,- 117 & ,073 & ,105 &,- 010 & ,016 \\
\hline
\end{tabular}


Dalam penelitian ini dilakukan interpretasi terhadap sembilan faktor yang terbentuk. Sembilan faktor ini terbentuk dari mereduksi variabel indikator yang dianggap berpengaruh terhadap preferensi masyarakat pada produk tabungan bank syariah dalam penelitian ini. Interpretasi ini didasarkan pada nilai loading menunjukkan besar korelasi antara suatu variabel dengan faktor 1 , faktor 2, faktor 3 , faktor 4 , faktor 5 , faktor 6 , faktor 7 , faktor 8 , dan faktor 9 .

Tabel. Hasil Ringkasan Indikator Terbentuk dengan Rotasi Varimax

\begin{tabular}{|c|c|c|c|c|c|}
\hline Indikator & $\begin{array}{c}\text { Faktor yang } \\
\text { terbentuk }\end{array}$ & $\begin{array}{l}\text { Eigenv } \\
\text { alue }\end{array}$ & $\begin{array}{l}\text { Loading } \\
\text { faktor }\end{array}$ & $\begin{array}{c}\% \\
\text { Varians }\end{array}$ & $\begin{array}{c}\% \\
\text { Kumula } \\
\text { tif }\end{array}$ \\
\hline $\begin{array}{l}\text { 1. Nisbah bagi hasil saling } \\
\text { menguntungkan (BS9) } \\
\text { 2. Jaminan tabunngan bagi hasil } \\
\text { tidak merugikan (BS6) } \\
\text { 3. Nisbah bagi hasil adil dan } \\
\text { trnasparan (BS8) }\end{array}$ & $\begin{array}{c}\text { Faktor Jaminan } \\
\text { Dan } \\
\text { Kesederajatan } \\
\text { Bagi Hasil }\end{array}$ & 7,138 & 0,810 & 23,793 & 23,793 \\
\hline $\begin{array}{l}\text { 1. Informasi produk yang sesuai } \\
\text { (AP7) } \\
\text { 2. Fungsi produk yang } \\
\text { bermanfaat (AP6) } \\
\text { 3. Sumber informasi nasabah } \\
\text { dari berbagai media (PS11) } \\
\text { 4. Image bank yang baik (AP9) } \\
\text { 5. Harga yang lebih terjangkau } \\
\text { (AP5) } \\
\text { 6. Prosedur aplikasi sederahana } \\
\text { (AP10) } \\
\text { 7. Produk yang inovatif (AP8) }\end{array}$ & $\begin{array}{c}\text { Faktor Fitur } \\
\text { Produk }\end{array}$ & 2,748 & $\begin{array}{l}0,541 \\
0,529\end{array}$ & 9,161 & 32,955 \\
\hline $\begin{array}{l}\text { 1. Tingkat keamanan produk } \\
\text { (AP1) } \\
\text { 2. Fasilitas produk yang } \\
\text { memadai (AP3) } \\
\text { 3. Kemudahan akses produk } \\
\text { (AP2) } \\
\text { 4. Tampilan yang unik dan } \\
\text { menarik (AP4) } \\
\text { 5. Pemahaman nasabah tentang }\end{array}$ & $\begin{array}{l}\text { Faktor Kuallitas } \\
\text { Atribut Produk }\end{array}$ & 2,048 & 0,809 & 6,825 & 39,780 \\
\hline
\end{tabular}




\begin{tabular}{|c|c|c|c|c|c|c|}
\hline & $\begin{array}{l}\text { kontrak bagi hasil dengan } \\
\text { bank (BS7) }\end{array}$ & & & & & \\
\hline & $\begin{array}{l}\text { Memberikan informasi nisbah } \\
\text { bagi hasil (BS3) } \\
\text { Pengetahuan nisbah } \\
\text { berdasarkan kesepakatan } \\
\text { (BS2) } \\
\text { Pengetahuan nisbah } \\
\text { keuntungan berdasarkan } \\
\text { prosentasi (BS1) } \\
\text { Return bergantung dari kinerja } \\
\text { bisnis (BS5) } \\
\text { Penambahan imbalan/return } \\
\text { secara akumulatif (BS4) }\end{array}$ & $\begin{array}{l}\text { Faktor Distribusi } \\
\text { Bagi Hasil }\end{array}$ & 1,750 & 0,590 & 5,832 & 45,612 \\
\hline & $\begin{array}{l}\text { Keluarga menjadi faktor } \\
\text { pendorong (PS8) } \\
\text { Mayoritas orang } \\
\text { menggunakan produk } \\
\text { tabungan syariah (PS9) } \\
\text { Dapat menerima informasi } \\
\text { dengan baik (PS7) }\end{array}$ & Faktor Lingkugan & 1,590 & 0,833 & 5,299 & 50,911 \\
\hline 3. & $\begin{array}{l}\text { Ketentuan produk tabungan } \\
\text { syariah mudah dipahami (PS3) } \\
\text { Memiliki pemahaman produk } \\
\text { tabungan syariah yang baik } \\
\text { (PS2) } \\
\text { Kesesuaian produk tabungan } \\
\text { dengan prinsip syariah dan } \\
\text { keadilan (PS4) }\end{array}$ & $\begin{array}{c}\text { Faktor } \\
\text { Pemahaman } \\
\text { Syariah }\end{array}$ & 1,429 & 0,644 & 4,762 & 55,675 \\
\hline 1. & $\begin{array}{l}\text { Mekanisme tabungan syariah } \\
\text { berbeda dengan konvensional } \\
\text { (PS5) }\end{array}$ & $\begin{array}{c}\text { Faktor } \\
\text { Mekanisme } \\
\text { Syariah }\end{array}$ & 1,313 & 0,790 & 4,378 & 60,053 \\
\hline 1. & $\begin{array}{l}\text { Produk tabungan yang } \\
\text { menarik dari segi akad (PS1) } \\
\text { Tabungan syariah berguna } \\
\text { dalam kebutuhan ekonomi } \\
\text { (PS6) }\end{array}$ & Faktor Kegunaan & 1,192 & 0,525 & 3,974 & 64,027 \\
\hline & $\begin{array}{l}\text { Produk sesuai gaya hidup dan } \\
\text { prinsip non riba (PS10) }\end{array}$ & $\begin{array}{c}\text { Faktor Kesesuaian } \\
\quad \text { Syariah }\end{array}$ & 1,069 & 0,610 & 3,562 & 67,589 \\
\hline
\end{tabular}


Pembagian faktor ini tergantung pada nama-nama faktor yang menjadi atau mendominasi pada suatu kelompok faktor tersebut. Menurut Ghozali (2016), pemberian nama-nama pada faktor baru yang terbentuk bersifat subjektif, kadang-kadang variabel yang memiliki nilai faktor loading tertinggi digunakan untuk memberi nama faktor

\section{Uji Chi-Square}

Setelah diketahui adanya 9 (sembilan) faktor terbentuk yang mempengaruhi minat masyarakat pada produk tabungan Bank Syariah, untuk mengetahui apakah terdapat hubungan asosiasi antara karakteristik responden dengan faktor-faktor yang telah terbentuk sebelumnya, maka hal tersebut di uji menggunakan uji Chi Square $\left(X^{2}\right)$ atau Cross Tabulation. Dari analisis Chi-Square dapat diketahui bahwa terdapat beberapa indikator dari faktor yang terbentuk memiliki hubungan yang asosiatif dengan karakteristik responden yang terdiri dari pekerjaan, usia, jenis kelamin, pendidikan terakhir dan alamat.

a. Jenis Kelamin (responden) dengan indikator nisbah bagi hasil yang diberikan oleh bank syariah saling menguntungkan kedua belah pihak.

Dari uji Chi- Square diketahui bahwa nilai signifikansi sebesar $0,027<$ 0,05. Hal itu menunjukkan bahwa jenis kelamin responden memiliki pengaruh terhadap pernyataan nisbah bagi hasil yang diberikan oleh bank syariah saling menguntungkan kedua belah pihak. Responden perempuan cenderung lebih setuju bahwa nisbah bagi hasil Bank Syariah saling menguntungkan. Sedangkan responden laki-laki lebih banyak ragu-ragu pada pernyataan tersebut.

b. Pendidikan terakhir (responden) dengan indikator Nisbah bagi hasil tabungan syariah yang diterapkan adil dan transparan.

Dari uji Chi- Square diketahui bahwa nilai signifikansi sebesar $0,034<$ 0,05. Hal itu menunjukkan bahwa pendidikan terakhir responden memiliki pengaruh terhadap pernyataan nisbah bagi hasil tabungan syariah yang diterapkan adil dan transparan. Responden dengan pendidikan SMA dan S1/S2/S3 samasama cenderung setuju bahwa nisbah bagi hasil Bank Syariah yang diterapkan adil dan transparan.

c. Pekerjaan (responden) dengan indikator menabung di bank syariah memiliki tingkat keamanan yang tinggi karena diawasi oleh lembaga terpercaya.

Dari uji Chi- Square dapat diketahui bahwa nilai signifikansi sebesar 0,046 
$<0,05$. Hal itu menunjukkan bahwa pendidikan terakhir responden memiliki pengaruh terhadap pernyataan "saya merasa bahwa menabung di bank syariah memiliki tingkat keamanan yang tinggi karena diawasi oleh lembaga terpercaya". Responden yang berprofesi sebagai karyawan swasta sangat setuju bahwa menabung di bank syariah memiliki tingkat kemanan yang tinggi mempengaruhi minat mereka, sedagakan responden yang memiliki profesi PNS, pelajar dan pensiunan cenderung setuju bahwa tingkat kemanan yang tinggi mempengaruhi minat mereka untuk menabung di bank syariah.

d. Usia (responden) dengan indikator mayoritas orang di lingkungan saya menggunakan produk tabungan dari Bank Syariah.

Dari uji Chi- Square diketahui bahwa nilai signifikansi sebesar $0,026<$ 0,05 . Hal itu menunjukkan bahwa usia responden memiliki pengaruh terhadap pernyataan "Mayoritas orang di lingkungan saya menggunakan produk tabungan dari Bank Syariah”. Keseluruhan responden baik yang berusia 17 tahun hingga >31 tahun sama-sama cenderung setuju bahwa mayoritas lingkungan responden menggunakan tabungan bank syariah.

e. Alamat (responden) dengan indikator keluarga menjadi faktor yang mendorong dalam menggunakan produk tabungan syariah.

Dari uji Chi- Square dapat diketahui bahwa nilai signifikansi sebesar 0,010 $<0,05$. Hal itu menunjukkan bahwa alamat responden memiliki pengaruh terhadap pernyataan. Masyarakat kota Pamulang, Serpong dan Pondok Aren cenderung setuju bahwa keluarga menjadi faktor pendorong yang mempengaruhi minat menabung mereka di Bank Syariah, sedangkan masyarakat Ciputat cenderung raguragu dengan pernyataan tersebut.

\section{E. KESIMPULAN}

Dengan menggunakan metode analisis faktor, 30 indikator variabel yang sudah ada kemudian tereduksi menjadi 9 faktor baru yang mempengaruhi minat masyarakat pada produk tabungan bank syariah. Faktor-faktor tersebut ialah faktor jaminan dan kesederajatan bagi hasil, faktor fitur produk, faktor kualitas produk, faktor distribusi bagi hasil, faktor lingkungan, faktor pemahaman syariah, faktor mekanisme syariah, faktor kegunaan, dan faktor kesesuaian syariah. Faktor jaminan dan kesederajatan bagi hasil menjadi faktor yang paling dominan dalam 


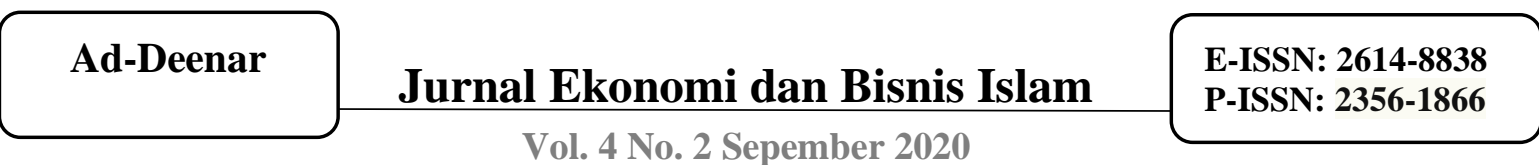

penelitian ini. Pada dasarnya semua faktorfaktor yang terdapat dalam penelitian ini berpengaruh terhadap preferensi masyarakat pada produk tabungan di bank syariah namun faktor lain tersebut bukan merupakan faktor yang dominan.

Adapun hasil penelitian ini juga menunjukkan adanya hubungan atau

Ali, Karnia. 2017. Pengaruh Promosi dan Atribut Produk Terhadap Keputusan Nasabah Dalam Memilih Tabungan Ekasave Pada Bank Eka Kantor Pusat Metro. Jurnal Derivatif Vol. 11 No. 1

Amelia, Erika. 2006. Faktor-Faktor yang Mempengaruhi Keputusan Customer untuk Menggunakan Jasa Hotel Syariah (Studii Kasus: Hotel Sofyan Betawi Syariah). Jakarta: Pascasarjana UI

Chotifah, Yuliana S. 2018. Peningkatan minat menabung di bank syariah melalui program office channeling. Journal of Finance and Islamic Banking Vol.1 No.1 Januari-Juni

Daulay, Raihanah. 2014. Pengaruh kualitas pelayanan dan bagi hasil terhadap keputusan menabung nasabah pada bank syariah mandiri kota medan. Jurnal menejemen $\&$ bisnis vol.10 no. 1

Firza, Aulia Viranti, dan Ginanjar A. 2015. Influence of Facilities, Promotion, Product and Location Islamic Banking on Decision Non Muslim Customers Patronizing at BRIS Case Study in BRI Syariah. The Journal of Tauhidinomics Vol. 1 No. 1. 35-60.

Hidayat, Anwar. 2014. Penjelasan Analisisi Faktor. www.statistika.com diakses pada 24 Meii 2019

Hutomo, Rusdianto \& Chanafi Ibrahim. 2016. Pengaruh Produk Bank Syariah Terhadap Minat Menabung Dengan Persepsi Masyarakat Sebagai Variabel keterkaitan antara karakteristik responden dengan faktor-faktor yang terbentuk. Karakteristik responden tersebut antara lain, jenis kelamin, pendidikan terakhir, pekerjaan, usia dan alamat responden.

\section{DAFTAR PUSTAKA}

\section{Sumber dari Jurnal}

Moderating Di Pati. Equilibrium: Volume 4, Nomor 1.

Indah Mulia Sari, Hendro Wibowo \& Edy Suprapto. 2015. Factors that Influenced People to Become Islamic Bank customer: a study on kancana Villagers. Al-Iqtishad: Vol. VII No. 1

Kontot, K, etc. 2016. Determining Factors Of Customer Preferences: A Case Of Deposit Products In Islamic Banking. Science Direct: Social And Behavioral Sciences 224. Pp. 167-175.

Mayangsari, Rini dan Rusda Irawati. 2018. Analisis Faktor - Faktor Yang Dipertimbangkan Konsumen Dalam Keputusan Pembelian Produk Kek Pisang Villa Kota Batam. Journal of Applied Business Administration: Vol 2, No 2,September 2018, hlm. 228-241. eISSN:2548-9909.

Md. Abdul Jalil \& Muhammad Khalilur Rahman. 2014. The Impact of Islamic Branding on Consumer Preference towards Islamic Banking Services: An Empirical Investigation in Malaysia. Journal of Islamic Banking and Finance March 2014, Vol. 2, No. 1, pp. 209-229

Raharjo, Sahid. 2018. Panduan Analisis Faktor dan Intrepretasi Dengan SPSS Lengkap. $\quad$ www.spssindonesia.com diakses pada 24 Mei 2019

Rohmah, Ika R.Q dan A. Roziq. Variabel penentu dan ekskalasi jumlah tabungan mudharabah di bri syariahcabang jember. Jurnal ilmiah vol.1 no.10 
Roni, Andespa. 2018. Pengaruh atribut produk terhadap minat menabung nasabah di bank syariah. Maqdis: Jurnal Kajian Ekonomi Islam- vol.3 no.2.

Siregar, Mulya, E. 2019. Tantangan Perbankan Syariah 2019. http://harianjogja.com diakses pada 12 Agustus 2019

Suhardi, Gunarto. 2008. Pengaruh Atribut Produk Yang Dipertimbangkan dalam Pemilihan Produk Deposito Perbankan Terhadap Kepercayaan dan Dampaknya pada Loyalitas Nasabah. KINERJA: Jurnal Volume. 12 No. 1 hal. 100-109.

Utami, Meinarini Catur. 2013. Analisis Faktor-Faktor Yang Mempengaruhi Dosen Dalam Melanjutkan S3 Dengan Metode Princypal Component Analysis. Studi Informatika: Jurnal Sistem Informasi, 6 (1), 2013, 1-7.

www.ojk.go.id

\section{Sumber dari Buku}

Abu Sinn, Ahmad Ibrahim. 2012. Manajemen Syariah: sebuah kajian historis dan kontemporer. Jakarta: Rajawali Pers

Ansori, Muhammad Ghofur. 2007. Perbankan Syariah di Indonesia. Yogyakarta: UGM Press

Antonio, M. Syai'i. 2012. Bank Syariah: dari Teori ke Paraktek. Jakarta: Gema Insani.

Arifin, Zainul. 2009. Dasar - dasar manajemen Bank Syariah. Jakarta: Pusat Alvabet

Darmawi, Herman. 2011. Manajemen Perbankan, Jakarta: Bumi Aksara.

Ferdinand, A. 2014. Metode Penelitian Manajemen: pedoman penelitian untuk penulisan skripsi, tesis, dan disertasi Sugiyono. 2015. Metode Penelitian Pendidikan Pendekatan Kuantitatif, Kualitatiff, dan $R$ \& D. Bandung: Afabeta ilmu manajemen. Edisi ke-5 Semarang: BP Universitas Diponegoro.

Ghozali, Imam. 2016. Aplikasi Analisis Multivariate dengan Program SPSS. Semarang: Badan Penerbit Universitas Diponegoro.

Gitosudarmo, I. 2014. Manajemenn pemasaran. Yogyakarta: BPFE UGM.

Hamid, Abdul. 2010. Panduan penulisan skripsi. Jakarta: UIN Press.

Karim, Adiwarman A. 2013. Bank Islam: Analisis Fikih Dan Keuangan. Jakarta: PT. Raja Grafindo.

Kashmir, 2012. Bank dan Lembaga Keuangan Lainnya. Jakarta: Raja Grafindo Persada.

Kotler, P dan Armstrong G. 2012. PrinsipPrinsip Pemasaran jilid 1 (Ed. Ke-1). Jakarta: Erlangga.

Kotler, P dan Kevin Lane Keller. 2016. Manajemen Pemasaran. Jakarta : Erlangga.

Muhammad. 2008. Manajemen Pembiayaan Mudharabah di Bank Syariah: Strategi Memaksimalkan Return dan Meminimalkan Return Pembiayaan di 163 Bank Syariah sebagai Akibat Masalah Agency. Jakarta: PT Raja Grafindo Persada.

Rivai, Veithzal, dkk. 2017. Kepemimpinan dan Perilaku Organisasi. Ed. 4. Jakarta: Rajawali Pers.

Santoso, Singgih. 2017. Stastistik Multivariat dengan SPSS. Jakarta: Elex Media Komputindo

Sugihartono, dkk. 2013. Psikologi Pendidikan. Yogyakarta: UNY Press.

Sugiyono. 2011. Metode Penelitian Kuantitatif, Kualitatiff, Dan R\& D. Bandung: Afabeta.

Sumarwan, Ujang. 2002. Perilaku Konsumen (Teori dan Penerapannya dalam Pemasaran). Bogor: Ghalia Indonesia. 
Sumarwan, Ujang. 2011. Perilaku Konsumen

(Teori dan Penerapannya dalam Pemasaran). Jakarta: PT. Raja Grafindo Persada

Sunaryo. 2014. Psikologi untuk keperawatan. Jakarta: EGC

Sunyoto, Danang. 2013. Teori, Kuesioner Dan Analisisi Data: Untuk Pemasaran Dan Perilaku Konsumen. Yogyakarta: Graha Ilmu

Suryani, Tatik. 2008. Perilaku Konsumen: Implikasi Pada Strategi Pemasaran. Yogyakarta: Graha Ilmu.

Tjiptono, Fandy. 2014. Pemasaran Jasa: Prinsip, Penerapan, dan Penelitian. Yogyakarta : ANDI
Tjiptono, Fandy. 2015. Strategi Pemasaran. Yogyakarta: ANDI

Trihendra, C. 2010. Step by step SPSS 18: Analisis Data Statistik. Yogyakarta: ANDI.

Walgito, Bimo. 2010. Pengantar Psikologi Umum. Yogyakarta: ANDI

Widarjono, Agus. 2015. Analisis Multivariat Terapan. Edisi kedua. Yogyakarta: UPP STIM YKPN.

Wiroso. 2010. Penghimpunan Dana Dan Distribusi Hasil Usaha Bank Syariah. Jakarta: PT. Grafindo.

Zuriah, Nurul. 2007. Metodologi Penelitian Sosial Dan Pendidikan. Jakarta: Bumi Aksara. 
